\title{
HIF2 and endocrine neoplasia: an evolving story
}

\author{
Eamonn R Maher ${ }^{1,2}$ \\ ${ }^{1}$ Department of Medical Genetics, University of Cambridge, Cambridge, UK and ${ }^{2}$ Department of Clinical Genetics, \\ Cambridge University Hospitals NHS Foundation Trust, Cambridge Biomedical Research Campus, Cambridge \\ CB2 OQQ, UK
}

Correspondence should be addressed to E R Maher Email erm1000@medschl.cam.ac.uk

\begin{abstract}
In this issue of Endocrine-Related Cancer, Toledo et al. report the identification of activating mutations in the HIF2 (EPAS1) transcription factor in a subset of sporadic pheochromocytomas and paragangliomas. These findings add significantly to an evolving and complex story of the role of hypoxic gene response pathways in human endocrine neoplasia.
\end{abstract}

The heterodimeric HIF transcription factors regulate cellular responses to hypoxia. Each heterodimer consists of a specific $\alpha$-subunit (HIF1 $\alpha$, HIF2 $\alpha$ and HIF3 $\alpha$ ) which, in hypoxic conditions, complexes with the HIF $\beta$ (ARNT) subunit (Kaelin \& Ratcliffe 2008). The best characterised factors, HIF1 and HIF2, have overlapping, but differing, roles in the hypoxic gene response. Thus, HIF1 and HIF2 regulate expression of $\sim 200$ genes implicated in angiogenesis, energy metabolism, cell proliferation and apoptosis, and while some targets are shared, others are preferentially regulated by HIF1 (BNIP3) or HIF2 (CCND1, VEGF) (Raval et al. 2005). Interestingly, in renal tumours, whereas HIF2 has been demonstrated to drive oncogenesis, loss-of-function mutations have been described in HIF1A and it has been suggested that HIF1 might have a tumour suppressor effect (Morris et al. 2009, Shen et al. 2011). HIF $1 \alpha$ and HIF2 $\alpha$ contain an N-terminal and a C-terminal transactivation domain (NTAD and CTAD). HIF $\beta$ is stably expressed but HIF $\alpha$ subunits are unstable and intracellular levels of HIF1 and HIF2 are primarily regulated by stabilisation of the HIF $\alpha$ subunits. Thus, in normoxic conditions, a family of prolyl hydroxylases modify two proline residues near the NTAD that enable the VHL tumour suppressor gene product ( $\mathrm{pVHL}$ ) (which acts as the substrate recognition subunit of an E3-ubiquitin ligase complex) to bind to HIF $\alpha$ and target it for degradation (Kaelin \& Ratcliffe 2008). In hypoxia, the oxygen-dependent prolyl hydroxylases are inactive, pVHL-dependent degradation of HIF $\alpha$ subunits is compromised and HIF1 and HIF2 are stabilised and activate downstream transcriptional pathways.

A notable feature of pheochromocytoma and paraganglioma is the high incidence of inherited cases such that germline mutations in at least ten genes (e.g. NF1, RET, SDHA, SDHAF2, SDHB, SDHC, SDHD, TMEM127, $M A X$ and $V H L$ ) can be detected in more than one third of all cases (Gimenez-Roqueplo et al. 2012, Jafri \& Maher 2012). Interestingly, inherited pheochromocytomas and paragangliomas can be subdivided by gene expression profiling studies according to the activity of hypoxic gene response pathways. Thus, activation of HIF-regulated pathways is seen in von Hippel-Lindau (VHL) disease and succinate dehydrogenase $(\mathrm{SDH})$ subunit-associated tumours but not in pheochromocytomas and paragangliomas associated with NF1, RET, TMEM127 and MAX mutations (Eisenhofer et al. 2004, Dahia et al. 2005, Pollard et al. 2006, Favier et al. 2009).

Sporadic pheochromocytomas and paragangliomas can also be subdivided according to hypoxic gene expression profiling with approximately half of tumours displaying a VHL/SDH-like profile (Dahia et al. 2005). Nevertheless, somatic inactivation of VHL- and SDH-subunit genes can

Published by Bioscientifica Ltd. 
be demonstrated in only a minority of sporadic cases, suggesting alternative mechanisms for activating hypoxic gene pathways (Eng et al. 1995, Astuti et al. 2004, Yao et al. 2010). Recently, several groups have demonstrated that oncogenic mutations in HIF2A/EPAS1 leading to HIF2 stabilisation can be implicated in the pathogenesis of pheochromocytomas and paragangliomas (Zhuang et al. 2012, Comino-Méndez et al. 2013, Lorenzo et al. 2013, Taïeb et al. 2013, Toledo et al. 2013, Yang et al. 2013).

Initially, Zhuang et al. (2012) reported two unrelated patients who presented with polycythaemia and paragangliomas harbouring gain-of-function $H I F 2 A$ mutations. Two different HIF2A missense substitutions (p.Ala530Thr and p.Ala530Val) affecting the same exon 12 residue were detected. Previously, germline HIF2A mutations (e.g. p.Pro534Leu, p.Gly537Arg, p.Met535Val, p.Gly537Trp, p.Asp539Glu) had been identified in patients with inherited erythrocytosis (Percy et al. 2008a,b, Furlow et al. 2009), and although the HIF2A mutations were not detected in normal tissues from the two patients described by Zhuang et al. (2012), the presence of polycythaemia and the respective mutations in multiple tumours from each patient (paragangliomas in one patient and a paraganglioma and somatostatinoma in the other) suggested that each of the individuals were likely to be mosaic for a HIF2A mutation that occurred post-zygotically. The p.Ala530 residue is adjacent to one of the two key proline residues (p.Pro531) whose hydroxylation status is critical for pVHL-mediated degradation of HIF2 $\alpha$ and Zhuang et al. (2012) demonstrated that both mutations impaired prolyl hydroxylation and promoted HIF $2 \alpha$ stabilisation. Subsequently, the same group reported two additional patients with polycythaemia, paragangliomas and somatostatinomas but novel HIF2A missense substitutions (p.Leu529Pro and p.Y532C) in tumour cells (Yang et al. 2013). In addition, Lorenzo et al. (2013) reported a germline activating HIF2A mutation (p.F374Y) (inherited from an apparently unaffected parent) in a patient with polycythaemia and paraganglioma.

Comino-Méndez et al. (2013) extended the clinical phenotype of tumour HIF2A mutations. Of seven patients with HIF2A mutation-positive tumours, three presented with congenital polycythaemia and multiple paragangliomas (p.Ala530Thr, p.Pro531Ser and p.Pro531Leu), one with multiple paragangliomas only (p.Ala530Val) and three with a single pheochromocytoma/paraganglioma (p.Ile533_Pro534del, p.Pro534_Asp536del and p.Asp 539Tyr). Following the detection of a somatic HIF2A mutation in six sporadic pheochromocytomas and paragangliomas analysed by exome sequencing, Toledo et al. (2013) found somatic HIF2A mutations in $2.3 \%$ $(4 / 167)$ sporadic tumours but not in inherited cases. Three mutations affected codon 531 (p.Pro531Thr, p.Pro531Ser and p.Pro531Leu) and were shown to be associated with increased HIF2 stability (transcriptional profiles were available for two tumours and these clustered with the pseudohypoxic group that contained tumours associated with VHL and $S D H X$ mutations).

In summary, recent studies of HIF2A mutations in pheochromocytoma and paraganglioma have provided novel insights into the role of hypoxic gene response pathways in the pathogenesis of endocrine neoplasia. To date, a number of common themes are emerging. First, most HIF2A mutations associated with pheochromocytoma and paraganglioma are somatic/mosaic and cluster in or around p.Pro531 resulting in HIF2 stabilisation producing gain-of-function effect. The clinical phenotype is variable, ranging from multiple tumours (paragangliomas or pheochromocytomas or paraganglioma and somatostatinoma) with or without polycythaemia to a single pheochromocytoma/paraganglioma. The role of HIF2 in endocrine neoplasia is now a hot research topic for research and much remains to be defined. From a clinical perspective, further information is required on the range of tumours that might be detected in patients who harbour constitutional or who are mosaic for HIF2A mutations - it would not be surprising if the phenotype expanded. A further key question is whether tumour HIF2A mutations will have implications for prognosis and treatment. Toledo et al. (2013) found evidence that HIF2A mutations at p.Pro531 promoted dedifferentiation of chromaffin cells and reduced the latency of tumour growth in nude mice assays. Malignant paragangliomas are known to be associated with germline $S D H B$ mutations and although malignancy has yet to be reported in HIF $2 A$-mutated tumours, the significance of HIF $2 A$ mutations for rate of tumour growth and risk of additional primary tumours in apparently sporadic cases needs to be determined. Although somatic HIF2A mutations may explain a subset of sporadic pheochromocytomas and paragangliomas with a pseudohypoxic gene expression profile, it would appear that additional, as yet uncharacterised, mechanisms must be implicated in other cases. Finally, although surgery is the mainstay of treatment for non-metastatic paragangliomas, much research is ongoing to develop anti-HIF therapies and it will be interesting to see whether, in the future, the finding of a HIF2A mutation in an endocrine tumour will have implications for clinical management.

Published by Bioscientifica Ltd. 


\section{Declaration of interest}

The author declares that there is no conflict of interest that could be perceived as prejudicing the impartiality of the research reported.

\section{Funding}

This research did not receive any specific grant from any funding agency in the public, commercial or not-for-profit sector.

\section{References}

Astuti D, Morris M, Krona C, Abel F, Gentle D, Martinsson T, Kogner P, Neumann HP, Voutilainen R, Eng C et al. 2004 Investigation of the role of SDHB inactivation in sporadic phaeochromocytoma and neuroblastoma. British Journal of Cancer 91 1835-1841. (doi:10.1038/ sj.bjc.6602202)

Comino-Méndez I, de Cubas AA, Bernal C, Alvarez-Escolá C, Sánchez-Malo C, Ramírez-Tortosa CL, Pedrinaci S, Rapizzi E, Ercolino T, Bernini G et al. 2013 Tumoral EPAS1 (HIF2A) mutations explain sporadic pheochromocytoma and paraganglioma in the absence of erythrocytosis. Human Molecular Genetics 22 2169-2176. (doi:10.1093/hmg/ddt069)

Dahia PL, Ross KN, Wright ME, Hayashida CY, Santagata S, Barontini M, Kung AL, Sanso G, Powers JF, Tischler AS et al. 2005 A HIF1 $\propto$ regulatory loop links hypoxia and mitochondrial signals in pheochromocytomas. PLoS Genetics 1 72-80. (doi:10.1371/journal.pgen.0010008)

Eisenhofer G, Huynh TT, Pacak K, Brouwers FM, Walther MM, Linehan WM, Munson PJ, Mannelli M, Goldstein DS \& Elkahloun AG 2004 Distinct gene expression profiles in norepinephrine- and epinephrine-producing hereditary and sporadic pheochromocytomas: activation of hypoxia-driven angiogenic pathways in von Hippel-Lindau syndrome. Endocrine-Related Cancer 11 897-911. (doi:10.1677/erc.1.00838)

Eng C, Crossey PA, Mulligan LM, Healey CS, Houghton C, Prowse A, Chew SL, Dahia PL, O'Riordan JL, Toledo SP et al. 1995 Mutations in the RET proto-oncogene and the von Hippel-Lindau disease tumour suppressor gene in sporadic and syndromic phaeochromocytomas. Journal of Medical Genetics 32 934-937. (doi:10.1136/jmg.32.12.934)

Favier J, Brière JJ, Burnichon N, Rivière J, Vescovo L, Benit P, Giscos-Douriez I, De Reyniès A, Bertherat J, Badoual C et al. 2009 The Warburg effect is genetically determined in inherited pheochromocytomas. PLOS ONE 4 e7094. (doi:10.1371/journal.pone.0007094)

Furlow PW, Percy MJ, Sutherland S, Bierl C, McMullin MF, Master SR, Lappin TR \& Lee FS 2009 Erythrocytosis-associated HIF- $2 \alpha$ mutations demonstrate a critical role for residues C-terminal to the hydroxylacceptor proline. Journal of Biological Chemistry 284 9050-9058. (doi:10.1074/jbc.M808737200)

Gimenez-Roqueplo AP, Dahia PL \& Robledo M 2012 An update on the genetics of paraganglioma, pheochromocytoma, and associated hereditary syndromes. Hormone and Metabolic Research 44 328-333. (doi:10.1055/s-0031-1301302)

Jafri M \& Maher ER 2012 The genetics of phaeochromocytoma: using clinical features to guide genetic testing. European Journal of Endocrinology 166 151-158. (doi:10.1530/EJE-11-0497)
Kaelin WG, Jr \& Ratcliffe PJ 2008 Oxygen sensing by metazoans: the central role of the HIF hydroxylase pathway. Molecular Cell 30 393-402. (doi:10.1016/j.molcel.2008.04.009)

Lorenzo FR, Yang C, Ng Tang Fui M, Vankayalapati H, Zhuang Z, Huynh T, Grossmann M, Pacak K \& Prchal JT 2013 A novel EPAS1/HIF2A germline mutation in a congenital polycythemia with paraganglioma. Journal of Molecular Medicine 91 507-512. (doi:10.1007/ s00109-012-0967-z)

Morris MR, Hughes DJ, Tian YM, Ricketts CJ, Lau KW, Gentle D, Shuib S, Serrano-Fernandez P, Lubinski J, Wiesener MS et al. 2009 Mutation analysis of hypoxia-inducible factors HIF1A and HIF2A in renal cell carcinoma. Anticancer Research 29 4337-4343.

Percy MJ, Furlow PW, Lucas GS, Li X, Lappin TR, McMullin MF \& Lee FS 2008 a A gain-of-function mutation in the HIF2A gene in familial erythrocytosis. New England Journal of Medicine 358 162-168. (doi:10.1056/NEJMoa073123)

Percy MJ, Beer PA, Campbell G, Dekker AW, Green AR, Oscier D, Rainey MG, van Wijk R, Wood M, Lappin TR et al. 2008b Novel exon 12 mutations in the HIF2A gene associated with erythrocytosis. Blood 111 5400-5402. (doi:10.1182/blood-2008-02-137703)

Pollard PJ, El-Bahrawy M, Poulsom R, Elia G, Killick P, Kelly G, Hunt T, Jeffery R, Seedhar P, Barwell J et al. 2006 Expression of HIF- $1 \alpha$, HIF- $2 \alpha$ (EPAS1), and their target genes in paraganglioma and pheochromocytoma with VHL and SDH mutations. Journal of Clinical Endocrinology and Metabolism 91 4593-4598. (doi:10.1210/jc.2006-0920)

Raval RR, Lau KW, Tran MG, Sowter HM, Mandriota SJ, Li JL, Pugh CW, Maxwell PH, Harris AL \& Ratcliffe PJ 2005 Contrasting properties of hypoxia-inducible factor 1 (HIF-1) and HIF-2 in von HippelLindau-associated renal cell carcinoma. Molecular and Cellular Biology 25 5675-5686. (doi:10.1128/MCB.25.13.5675-5686.2005)

Shen C, Beroukhim R, Schumacher SE, Zhou J, Chang M, Signoretti S \& Kaelin WG, Jr 2011 Genetic and functional studies implicate HIF1 $\alpha$ as a $14 \mathrm{q}$ kidney cancer suppressor gene. Cancer Discovery $1222-235$. (doi:10.1158/2159-8290.CD-11-0098)

Taïeb D, Yang C, Delenne B, Zhuang Z, Barlier A, Sebag F \& Pacak K 2013 First report of bilateral pheochromocytoma in the clinical spectrum of HIF2A-related polycythemia-paraganglioma syndrome. Journal of Clinical Endocrinology and Metabolism 98 E908-E913. (doi:10.1210/jc. 2013-1217)

Toledo RA, Qin Y, Srikantan S, Morales NP, Li Q, Deng Y, Kim S, Pereira MA, Toledo SP, Su X et al. 2013 In vivo and in vitro oncogenic effects of HIF2A mutations in pheochromocytomas and paragangliomas. Endocrine-Related Cancer 20 349-359. (doi:10.1530/ERC-13-0101)

Yang C, Sun MG, Matro J, Huynh TT, Rahimpour S, Prchal JT, Lechan R, Lonser R, Pacak K \& Zhuang Z 2013 Novel HIF2A mutations disrupt oxygen sensing, leading to polycythemia, paragangliomas, and somatostatinomas. Blood 121 2563-2566. (doi:10.1182/ blood-2012-10-460972)

Yao L, Barontini M, Niederle B, Jech M, Pfragner R \& Dahia PL 2010 Mutations of the metabolic genes IDH1, IDH2, and SDHAF2 are not major determinants of the pseudohypoxic phenotype of sporadic pheochromocytomas and paragangliomas. Journal of Clinical Endocrinology and Metabolism 95 1469-1472. (doi:10.1210/jc.2009-2245)

Zhuang Z, Yang C, Lorenzo F, Merino M, Fojo T, Kebebew E, Popovic V, Stratakis CA, Prchal JT \& Pacak K 2012 Somatic HIF2A gain-of-function mutations in paraganglioma with polycythemia. New England Journal of Medicine 367 922-930. (doi:10.1056/NEJMoa1205119)

Received in final form 23 April 2013

Accepted 25 April 2013

Made available online as an Accepted Preprint

7 May 2013 http://erc.endocrinology-journals.org DOI: 10.1530/ERC-13-0146
(C) 2013 Society for Endocrinology Printed in Great Britain 